\title{
EDUCATION ACTUALITIES IN POLAND: AN INTERVIEW WITH ANNA KLIM-KLIMASZEWSKA
}

\author{
Vincentas Lamanauskas \\ Šiauliai University, Lithuania
}

Each country's education system is individual and unique, regardless of common and universal things. On the other hand, the expectations of the inhabitants in every country basically coincide - everybody wants to acquire a qualitative education. In Lithuania such an aim is declared. It is to be thought, that education aims of Poland are the same. However, whatever good the experience of other countries was, the attempts to blindly follow the other countries' education experience and learnt lessons, is not purposeful. In Lithuania such attempts constantly happen. Certainly, this does not deny the importance of other countries' experience, cognition of such experience. Experience and recommendations are very important. We can and have to learn one from each other. So, in this interview we are talking to Anna Klim-Klimaszewska.

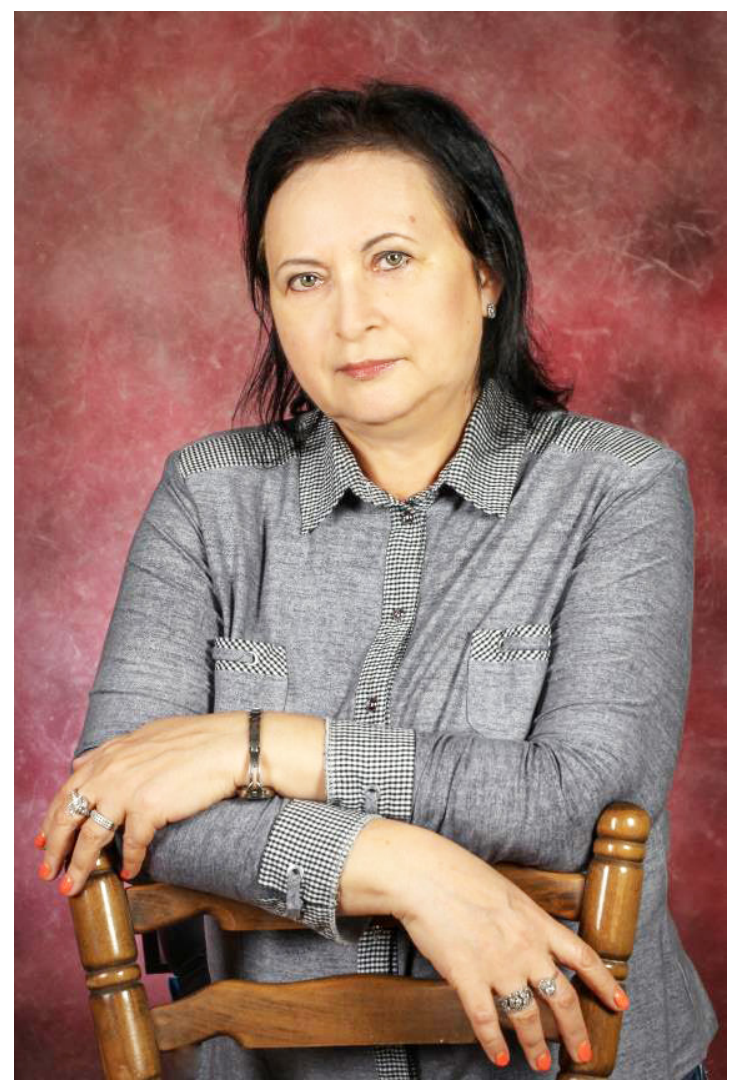

Dr. Anna Klim-Klimaszewska is a professor of pedagogy. She works at the university of Natural Sciences and Humanities in Siedlce, Poland. She has many years of experience in scientific and pedagogical work. She has also published more than 250 scientific works. Professor Anna is an active and productive scientist with particular emphasis on research on childhood education.

It is possible to find more detailed information (in Polish) here: http:// www.insib.uph.edu.pl/images/ Bibliogramy/Klimaszewska.pdf. 


\section{Introduce yourself briefly to the journal readers}

My name is Anna Klim-Klimaszewska. I am a professor of pedagogy. I work at the University of Natural Sciences and Humanities in Siedlce, Poland. I train preschool teachers and early primary education teachers (grades 1 to 3 ).

It would be interesting to know a bird's-eye-view of the education system in your country in general, that is from primary to tertiary level. Can you describe the education system in your home country?

Full-time compulsory education in Poland lasts 9 years and covers the last year of pre-school education and 8-year primary school.

The Polish system differentiates between full and part-time education. Full-time compulsory education in school settings concerns the children and young people aged 7-15. Part-time compulsory education concerns students aged 15-18 and may be organized in the form of secondary school or at the employer's premises (within the framework of vocational training).

Education system in Poland comprises:

- pre-school education,

- primary education,

- secondary education,

- post-secondary non-tertiary education,

- higher education,

- adult education and training.

Early childhood education is organised in nursery schools, pre-school classes in primary schools and pre-school units or centres and is compulsory for 6-year-old children who are to commence primary education next years at the 1st grade of primary school.

Primary education comprises 8-year primary school attended by pupils between the ages of 6/7 and 15.

General education in 8-year primary school is divided into two stages:

- grades 1 to 3 (early school education), implemented in the form of integrated teaching,

- $\quad$ grades 4 to 6 , with teaching arranged by subjects.

Secondary (post-primary) education comprises:

- 4-year general upper-secondary school,

- 5-year technical upper-secondary school,

- 3-year sectoral VET school (stage I),

- 2-year sectoral VET school (stage II).

At the completion of upper-secondary education, both general and technical, pupils may sit an external matriculation exam. It allows to obtain matriculation certificate and gain access to higher education. The matriculation examination is also available for students of stage I and II VET school.

Students of stage I VET school and technical upper-secondary school may, during the course of education or after its completion, sit external examinations confirming vocational qualifications and obtain a diploma confirming vocational qualifications. 
Post-secondary non-tertiary schools are included in the Polish classification as part of secondary education. Post-secondary schools enable students who have completed general upper-secondary education to acquire a diploma confirming vocational qualifications upon passing vocational examination. Post-secondary schools offer programmes lasting from 1 up to 2.5 years. Students of post-secondary schools take the same vocational examinations as students of technical upper-secondary schools or VET schools.

There are two types of higher education institutions:

- a university-type higher education institution,

- a non-university-type higher education institution.

Both types of institutions offer first-cycle, second-cycle and/or long-cycle programmes, however only university-type higher education institutions are authorised to organize thirdcycle (doctoral) programmes and award doctoral degree.

Studies may have two basic organisational forms: full-time and part-time.

First-cycle programmes last:

- 3-4 years in case of a Bachelor's professional degree (licencjat),

- 3.5-4 years in case of a professional title of and Engineer (inżynier).

Access to second-cycle programmes is open to holders of a Bachelor's or Engineer's degree. Second-cycle programmes last 1.5 to 2 years, depending on the field of study.

In the fields of study specified by the Minister of Science and Higher Education, the programmes shall be provided as long-cycle programmes of a total duration of 4-6 years. These are the following: Medical Analytics, Pharmacy, Faculty of Medicine, Faculty of Medicine and Dentistry, Law, Canon Law, Veterinary Medicine and Physiotherapy.

First and second cycle programmes end with a diploma examination and obtaining a diploma of higher education following passing the exam.

Holding Master's degree entitles to practice in a given profession and provides access to doctoral programmes at university-type HEIs and research institutes, lasting 3-4 years.

Adult education and training is implemented on primary and secondary level and includes obtaining and complementing skills and qualifications for professional and personal goals. Adult education is provided in two forms (school and out-of-school):

- in public continuing education centres (CECs) and practical training centres (PTCs),

- in further and in-service training centres,

- $\quad$ as well as in the form of non-degree postgraduate programmes offered by higher education institutions.

There is also a separate system for training the unemployed and certain categories of job seekers.

It is obvious that teaching is a very important profession. Teachers need to be welleducated. How are teachers educated in your country?

Teacher education and training standards are formulated in the Regulation by the Minister of Science and Higher Education which regulates teacher training in Poland. Pursuant to that Regulation, higher education institutions shall provide training preparing for practising the profession of a teacher in degree programmes and post-graduate programmes within the framework of study modules. First-cycle education shall cover only preparation 
for the profession of a teacher in pre-school education and primary schools, whereas second-cycle and long-cycle programmes - preparation to work in all types of schools and educational units.

Preparation to practise as a teacher in the scope of teaching one subject (conducting classes) shall include compulsory preparation in the following areas:

1) Substantive - for teaching the first subject (conducting classes) - module 1; substantive preparation pursuant to the description of learning outcomes for the pursued field of study, in such a dimension as to ensure substantive preparation for teaching the subject (conducting classes) and in the number of ECTS credits allocated to the pursued field of study;

2) psychological-educational - module 2 (10 ECTS credits); covers general psychological-educational preparation ( 90 hours), psychological-educational preparation for teaching at a given educational stage or stages (60 hours) and practical training (30 hours);

3 ) teaching - module 3 (15 ECTS credits); covers the basics of teaching ( 30 hours), didactics of a subject (type of classes) at a given educational level(s) (90 hours) and practical training (120 hours).

Preparation to practise as a teacher in HEIs may be extended to include preparation:

1) for teaching another subject (teaching) - module 4; covers substantive preparation in a dimension ensuring substantive preparation for teaching another subject (conducting classes) and in the number of ECTS credits assigned to the field of study pursued, subject didactics (type of classes) at a given educational level or stages (60 hours) and practical training (60 hours) - both components of 10-15 ECTS credits;

2) in the field of special needs education - module 5 (25 ECTS credits); covers special psycho-educational education (140 hours), special needs didactics (90 hours) and practical training (120 hours).

Preparation to practise as a teacher in post-graduate programmes may be provided in the following areas:

1) preparation for teaching another subject (conducting classes) - module 4;

2) preparation in the psychological-educational and didactic field for university graduates having substantive preparation for teaching the subject (conducting classes) who do not have psychological, pedagogical and didactic preparation modules 2 and 3, whereas in the case of graduates of first-cycle studies, it may include only preparation for work in pre-school education and primary schools;

3) special needs education for people who are trained to practice teaching profession - module 5.

Implementation of each module, both at university and post-graduate level, leads to the achievement of the same educational results.

\section{When should children start formal schooling in your country?}

Children start formal schooling, i.e. the first grade of primary school, at the age of 7. However, parents of 6-year-olds have a choice: they can either leave their child at a preschool institution or send it to school. Should the parents decide that their child will begin 
schooling at the age of $6, \mathrm{~s} /$ he must undergo 1 year of compulsory pre-school (kindergarten) preparation at the age of 5 .

It is a well-known fact that students' motivation to learn is a key element in education. If children are motivated to learn and if we enable each one to learn effectively, we will have an education system with a great performance level. What about students' motivation to learn in your country?

There is a number of ways in which students can be motivated to study. The main motivation method used in Poland is assessment/grading - just, objective, justified, clear, serving student's career purposes and emphasising what the student knows. Students' motivation is further affected by the attractiveness of classes and methods of work, by praising, rewarding, and introducing elements of sound competition. Another important factor is supporting one's self-confidence and accounting for student's individual needs and interests. By motivating to study, teachers encourage student independence, allow one to make choices on their own, select activities which require students to act, enrich teaching with elements of games, and often organise group activities.

\section{What are the qualities of a good teacher from your point of view?}

In my opinion, a good teacher is well-educated, competent, and qualified to work with a given group of students. In addition, s/he is creative, enjoys his/her work, and is always well prepared for classes. A good teacher can not only pass on knowledge effectively, but first and foremost, has the ability to engage students in a subject, make them curious - inspire to learn and work independently. S/he is sociable, open, curious about the world, and self-development-oriented. A good teacher has faith in his/her students, believes in their abilities, and is an anchor for them. S/he is just, objective, can praise his/her students for the pettiest successes, never ridicules, helps them overcome difficulties, is both a partner, a guardian and a friend of students. Finally, a good teacher is a happy person, internally coherent, who has self-esteem and a positive attitude to life.

It is clear that each country's education system has both advantages and disadvantages. Could you briefly describe your country's basic education system challenges?

The Polish School continues to be a place where classes are held - classes focusing on communicating matters to be mastered. It is still inept when it comes to emotional education and the pedagogics of creativity. It is still insufficiently used as a place of valuable social practice. Contemporary school, student and education present numerous challenges to the teacher. The ability to cope in a dynamically changing environment, among young people and subsequent generations requires the teacher to be flexible, to swiftly adapt to new conditions, oriented at students' needs, to be able to understand social transformations, including above all any generation gaps. For the system of education to react properly to job market's needs, it needs to identify competency needs of employers in advance.

Contemporary education is more than simply passing on scientific developments. It is also - or perhaps most importantly - about the teaching of knowledge selection and its 
practical application. Socio-economic changes consequential to the development of modern information technologies, including but not limited to the Internet, and mobile technologies, make it necessary to remodel the systems of education. Therefore, an absolute priority nowadays is to develop e-learning, as this allows one to eliminate the time and distance obstacles. Classes may be run alive via a remote, interactive and mobile resource access. Despite the fact that e-learning is one of the modern forms of distance learning, it cannot replace the traditional forms. Nevertheless, it effectively supplements it.

New job market needs and changes in the system of education defined in the general education curriculum have led to the extension of typical teacher's roles to include new ones - those of an integrator, counsellor, guide, moderator, inspirer, etc. Teachers seeking means to create student development more and more often become one's coach or mentor. Students benefit from teacher-coaching by: better learning, greater independence, the feeling of causation, self-esteem development, ability to organise work, the feeling of being responsible for one's success, development of critical, reflexive, and analytical thinking skills. Teachers, in turn, benefit from coaching by: better student insight, use and reinforcement of student individual skills and talents, but also of one's own competencies. Even though schools relatively rarely employ coaches, the elements of the coaching method are used, such as supporting, asking questions, open-end questions, active listening, motivating, methods of defining a realistic goal and actions.

All in all, a strategic challenge facing the Polish system of education is to equip students with competencies to manage contemporary states and develop a competitive edge for our home economy in the globalised world. For there is no innovative economy without an innovative society.

Professor Anna Klim-Klimaszewska is an active, initiative scientist. On her initiative a scientific conference for discussing actual education questions is held annually in Siedlce. On May 23-25, 2017 the XV international conference on the topic "Orientations and Ventures in Education" took place. Every year researchers from Poland, Lithuania, Ukraine, Belorussia, Russia, Czechia, Hungary and other countries participate in the conference. This allows to more exhaustively cognize other countries' education situation, experience, problems to be solved, etc. During these conferences a lot of attention is paid to teacher education. It is important to perceive, that this is the main and universal principle of a successful education system, that functions everywhere - this is teacher's role. On behalf of the journal's editorial board we wish the professor success in her academic career.

Note: This interview was performed 24 May 2017, in Siedlce, Poland.

Received 29 October 2017; accepted 28 December 2017

Vincentas Lamanauskas

PhD., Professor, Department of Education, Siauliai University, P. Visinskio Street 25,

LT-76351 Siauliai, Lithuania.

E-mail: v.lamanauskas@ef.su.lt

Website: http://www.lamanauskas.puslapiai.lt

https://www.researchgate.net/profile/Vincentas_Lamanauskas 